\section{Spread intensity and invasiveness of sycamore maple (Acer pseudoplatanus L.) in Lithuanian forests}

\author{
Lina Straigyte, Virgilijus Baliuckas
}

The primary objectives of this study were to estimate seedling abundance, spread intensity, and invasiveness of sycamore maple (Acer pseudoplatanus L.) in Lithuanian forests. The species was introduced to Lithuania in 1802, and since then has subsequently become gradually invasive. Seedling understory abundance, colonization and dispersal were investigated in six forest blocks covering the principal sycamore distribution areas in southwestern Lithuania. Seedlings height and densities in the undestory were evaluated, and seedlings assigned to four height groups. Species invasiveness was estimated applying the Pest Plant Prioritization Process (PPPP), based on the Analytic Hierarchy Process (AHP) method. Results showed the average spread distance from the parent tree was $257 \mathrm{~m}$, with a mean seedling number per hectare of 2064 . Sycamore maple invasive score was 0.6426 (range: $0-1$ ), the current relative to potential distribution rating was 0.57 , and the social, environmental, and economic impact score was 0.1682 . Such values were used to assess the Pest Plant Score for sycamore maple, obtaining a value $(0.3537)$ lower than expectations (0.5). Results indicated that the species exhibits invasive properties and a rapid spread in the study area. Some implications of the above results in view of the upcoming climate change and the use of sycamore maple in Lithuanian forest plantations are discussed.

Keywords: Sycamore, Seedling spread, PPPP, Invasiveness, Pest Plant Score

\section{Introduction}

During the early $19^{\text {th }}$ century, the practice of planting non-native tree species in Lithuania was initiated with the primary goal of increasing wood productivity. It was unknown at the time certain species would successfully undergo naturalization, and subsequently exhibit a widespread geographic distribution, threatening natural ecosystems. Vitousek \& Walker (1989) characterized the alterations of the community stability and structure due to non-native tree species, which successfully proliferated and became invasive community members, limiting native plant growth (Lichstein et al. 2004). Boxelder (Acer negundo L.), black locust (Robinia pseudoacacia L.), and black cherry (Prunus serotina Ehrh.) are included in the list of invasive species in Lithuania, and additional

alien species are currently being considered for invasive status. One of the more problematic non-native species in Lithuania is the sycamore maple (Acer pseudoplatanus L., Sapindaceae), characterized by rapid growth (when grown on suitable sites) and potentially high timber prices (Hein et al. 2009). Sycamore maple is mostly a central-European, mountain species reaching its northeastern range limit in Poland. Sycamore is rarely found in pure stands covering small areas on steep slopes on limestones where it forms its own communities (Acerion pseudoplatani alliance - Jones 1945). More frequently it grows in mixed broad-leaved forests of the Carpinion and Alno-Padion alliances (Boratynski 1999). In Lithuania, the species grows in fertile moist sites and in secondary forests. Moreover, it is shade and

Aleksandras Stulginskis University, Faculty of Forest Science and Ecology, Institute of Forest Biology and Silviculture, Studentu 11, LT-53361 Akademija, Kaunas district (Lithuania)

\section{@ Lina Straigyte (lina.straigyte@asu.lt)}

Received: Sep 06, 2012 - Revised: Jul 26, 2013 - Final Acceptance: Feb 20, 2015

Citation: Straigyte L, Baliuckas V, 2015. Spread intensity and invasiveness of sycamore maple (Acer pseudoplatanus L.) in Lithuanian forests. iForest 8: 693-699 [online 2015-03-19] URL: http://www.sisef.it/iforest/contents/?id=ifor0763-006

Communicated by: Renzo Motta frost tolerant (Navasaitis 2004), and in naturally regenerated stands often grows mixed with ash (Binggeli 1992). Typically, the species begins bearing fertile seeds at approximately 20 to 30 years of age (Burschel \& Huss 1997, Navasaitis 2004).

Sycamore maple is well adapted to the current climatic conditions of central Europe, and is expected to expand beyond its current distributional limits (Kölling \& Zimmermann 2007, Kölling 2007). This species has become naturalized in many countries, including Spain, Turkey, Ireland, Sweden, North and South America, India, and New Zealand (Binggeli 1992, Rusanen \& Myking 2003). In Lithuania, sycamore maple may reach up to $24 \mathrm{~m}$ of height and $1 \mathrm{~m}$ of stem diameter (Januškevičius et al. 2006), and is mostly found in parks and gardens, with only few forest plantations.

The question we pose is whether sycamore maple may be considered an invasive nonnative tree in Lithuania. Williamson \& Fitter (1996) estimated that only approximately $10 \%$ of naturalized plant species become invasive and produce significant economic and ecological impacts. Historical records indicated sycamore maple was introduced to the Vilnius University Botanical Garden in 1802 (Skridaila 2001), and since then it readily spreads into local forest stands. Informed decisions must be made to control invasive trees in forests, which requires establishing the relative importance of each alien tree.

The principal objectives of this study were to estimate sycamore maple seedling abundance, spread intensity, and invasiveness in Lithuanian forests. Invasiveness was determined by evaluating the following questions: (i) how invasive is the species, i.e., how rapidly can it spread? (ii) what is the present and potential extent of the species? (iii) what are the social, environmental, and economic impacts of the species in Lithuania?

\section{Material and methods}

\section{Description of the study area}

The Lithuanian climate is transitional and varies from maritime in the west to continental in the east (Galvonaite et al. 2007). The mean annual temperature is approximately 6 ${ }^{\circ} \mathrm{C}$, and mean annual precipitation varies from 620 to $700 \mathrm{~mm}$ along an east-west gradient. Lithuania's terrain is an alternation of moderate lowlands and highlands, with a maximum elevation of nearly $300 \mathrm{~m}$. Alisov (1954) classifies Lithuania in the southwest sub-area climate of the South Baltic. In general, the country lies in boreal and broadleaved forest belts, and forests cover nearly $33 \%$ of the territory. The natural geographic range of hornbeam (Carpinus betulus L.) marks the border between the predominantly broadleaved zone to the south and the conif- 
erous zone to the north. Conifers constitute about $56.1 \%$ of the total forest area (source: State Forest Service). The main conifer species are Scots pine (about 35.3\%) and Norway spruce (about 20.8\%). Broadleaf trees dominate the central part of the country: birch constitutes about $22.2 \%$ of the total, followed by black alder (about 6.8\%) and European aspen (about 3.8\%). Other hardwoods make up $4.7 \%$ of the total forest area and consist of pedunculate oak $(2.0 \%)$, common ash $(1.8 \%)$ and other species (elms, hornbeam, etc.).

This study was conducted in six forest blocks, in south-western Lithuania (Tab. 1), differing in dominant tree species area and prevailing site type. The study area includes $40-90$ year old stands. Soil fertility was obtained from the forest inventory database. The dominant tree species were Pinus sylvestris L., Acer pseudoplatanus and Fagus sylvatica $\mathrm{L}$. The shrub layer was dominated by Acer pseudoplatanus, Sorbus aucuparia L. and Corylus avellana L. Acer pseudoplatanus and Fagus sylvatica are non-native to Lithuania.

\section{Seedling abundance and spread intensity}

The density of sycamore maple seedlings in the understorey was evaluated in each block per unit area and then reported to hectare Seedlings were grouped into four height groups: (1) < $0.5 \mathrm{~m}$; (2) $0.5-1.5 \mathrm{~m}$; (3) $1.5-3$ $\mathrm{m}$; (4) $>3 \mathrm{~m}$. No replicates per forest block were made as the data collection was performed in a comprehensive way (see below) to forest stand in areas larger than half a hectare at each site. The spread of sycamore maple was assessed by collecting the following information:

- latitude, longitude and altitude of the most likely parent tree or group of parental (mature) trees; in almost all cases mature trees were scattered over large areas and at considerable distance each other, so seedlings dispersal was considered from the closest mature tree;
- the area covered by sycamore maple in the understory from the parent tree in four directions $(\mathrm{N}, \mathrm{E}, \mathrm{S}$, and $\mathrm{W})$ : the number of seedlings along $5 \mathrm{~m}$-wide transects was recorded, and the average spread distance calculated based on mean values for all directions. The length of transects varied based on the seedling spread distance.

- the species composition in the canopy layer and the dominant tree species of the sampled stand;

- the relative density of the upper canopy layer on a scale 0 to 1.0 , where 1.0 indicates the highest density, following the procedure adopted by the Lithuanian $\mathrm{Na}$ tional Forest Inventory (2003-2007);

- the underbrush cover density was recorded as the coverage of the crown projection on the 5-m transect area $(0-100 \%)$.

Statistical analysis was carried out using SAS software (SAS Institute, Inc., SAS/ STAT software Release 9.3). SAS PROC CORR was used to calculate Pearson's pairwise correlation coefficients between seedling abundance and stand characteristics. The exact Kolmogorov-Smirnov twosample two-sided test (SAS PROC NPAR1WAY) was performed for testing differences in seedling height classes and densities among the six sites. The same test was used in the comparison of different seedling groups by site fertility and underbrush cover. Mantel test with 10000 permutations was carried out on a Euclidean distance matrix for similarity measures using densities of seedling height classes against a matrix of pairwise geographical distances between sites.

\section{Invasiveness assessment}

The Pest Plant Prioritisation Process (PPPP) was used to determine the invasiveness degree (Saaty 1995, Weiss \& McLaren 2002). PPPP is a prioritization process or risk assessment based on the Analytic Hierarchy Process (AHP), which ranks weeds (or invasive plant species) by: (1) assessing plant invasiveness; (2) comparing the species' present and potential distributions; and (3) determine the impacts of the plant on social, economic, and environmental values. The method described by Panetta \& Dodd (1987) and developed by the Biosciences Research Division of the Department of Primary Industries, Victoria, Australia (Anonymous 2004) was followed in this study. Weightings of each criteria were set using an expert system relying on multi-criteria analysis (Anonymous 2004). An intensity rating (score) was assigned to each species considered for each criteria listed in Tab. 3 based on the following scale: high (1), mediumhigh (0.75), medium (0.5), medium-low $(0.25)$, and low (0).

Invasiveness can be defined as the ability to establish, reproduce and disperse within an ecosystem. To assess a plant for both invasiveness and impact, information from a variety of sources including the scientific literature, databases, online information, journal articles and other sources was collected. Such information has been then grouped under several "criteria" that are listed in Tab. 3. For each criterion, an "intensity" value was assigned based on the following ratings: high (1.0); medium-high (0.75); medium (0.5); medium-low (0.25); and low (0.0). Wherever the information on a specific criterion was lacking, rating was set to 0.5 (medium). The scored ratings were then tallied and weighting for each criterion calculated to obtain an "invasiveness score" (IS) for maple (eqn. 1):

$$
I S=\left(W_{g} \cdot W_{c}\right) \cdot R_{i}
$$

where $W_{\mathrm{g}}$ and $W_{\mathrm{c}}$ are the weightings calculated for groups and criteria, respectively, and $R_{\mathrm{i}}$ is the intensity rating value based on the scale reported above. The closer the invasiveness score is to 1 , the more invasive the plant is.

Current and potential distributions are other major components required in the AHP. Current distribution of A. pseudoplatanus was derived from the Lithuanian Fo-

Tab. 1 - Descriptive data for the sycamore maple forest blocks used in this study. (*) Site Index: humidity (N, normal; L, temporarily wet); fertility (b, poor; c, fertile); soil texture (l, light soil; $\mathrm{p}$, two story soil). (SD): standard deviation.

\begin{tabular}{|c|c|c|c|c|c|c|c|c|c|c|}
\hline \multirow{2}{*}{ No } & \multirow{2}{*}{$\begin{array}{l}\text { Forest enterprise, } \\
\text { forest district }\end{array}$} & \multirow{2}{*}{ Region } & \multirow{2}{*}{$\begin{array}{l}\text { Climate } \\
\text { type }\end{array}$} & \multirow{2}{*}{$\begin{array}{c}\text { Latitude } \\
\text { Longitude }\end{array}$} & \multirow{2}{*}{$\begin{array}{l}\text { Altitude } \\
\text { a.s.l. (m) }\end{array}$} & \multirow{2}{*}{$\begin{array}{c}\text { Site } \\
\text { index* }\end{array}$} & \multirow{2}{*}{$\begin{array}{l}\text { Stand } \\
\text { age }\end{array}$} & \multirow{2}{*}{$\begin{array}{l}\text { No. seedlings } \\
\text { ha }^{-1}\end{array}$} & \multicolumn{2}{|c|}{ Seedling spread distance (m) } \\
\hline & & & & & & & & & Mean & SD \\
\hline 1 & $\begin{array}{l}\text { Silutes, } \\
\text { Rambyno }\end{array}$ & $\begin{array}{l}\text { West } \\
\text { southern }\end{array}$ & maritime & $\begin{array}{l}55^{\circ} 02^{\prime} 44^{\prime \prime} \\
22^{\circ} 05^{\prime} 35^{\prime \prime}\end{array}$ & 63 & $\mathrm{Ncl}$ & 60 & 2465 & 373 & 51 \\
\hline 2 & $\begin{array}{l}\text { Silutes, } \\
\text { Norkaiciu }\end{array}$ & $\begin{array}{l}\text { West } \\
\text { central }\end{array}$ & maritime & $\begin{array}{l}55^{\circ} 26^{\prime} 59^{\prime \prime} \\
21^{\circ} 32^{\prime} 17^{\prime \prime}\end{array}$ & 2 & $\mathrm{Ncl}$ & 90 & 3446 & 291 & 59 \\
\hline 3 & $\begin{array}{l}\text { Jurbarko, } \\
\text { Viesviles }\end{array}$ & $\begin{array}{l}\text { West } \\
\text { southern }\end{array}$ & maritime & $\begin{array}{l}55^{\circ} 04^{\prime} 52^{\prime \prime} \\
22^{\circ} 24^{\prime} 09^{\prime \prime}\end{array}$ & 24 & $\mathrm{Ncl}$ & 80 & 1354 & 210 & 119 \\
\hline 4 & $\begin{array}{l}\text { Jurbarko, } \\
\text { Viesviles }\end{array}$ & $\begin{array}{l}\text { West } \\
\text { southern }\end{array}$ & maritime & $\begin{array}{l}55^{\circ} 04^{\prime} 58^{\prime \prime} \\
22^{\circ} 24^{\prime} 25^{\prime \prime}\end{array}$ & 23 & $\mathrm{Ncl}$ & 60 & 492 & 134 & 71 \\
\hline 5 & $\begin{array}{l}\text { Dubravos, } \\
\text { Vaisvydavos }\end{array}$ & Central & transitional & $\begin{array}{l}54^{\circ} 50^{\prime} 38^{\prime \prime} \\
24^{\circ} 02^{\prime} 33^{\prime \prime}\end{array}$ & 79 & $\mathrm{Nbl}$ & 60 & 2528 & 209 & 34 \\
\hline 6 & $\begin{array}{l}\text { Dubravos, } \\
\text { Vaisvydavos }\end{array}$ & Central & transitional & $\begin{array}{l}54^{\circ} 51^{\prime} 26^{\prime \prime} \\
24^{\circ} 02^{\prime} 40^{\prime \prime}\end{array}$ & 68 & Nep & 40 & 2098 & 130 & 13 \\
\hline
\end{tabular}


Fig. 1 - A. pseudoplatanus seedling density as a function of the distance from the likely parent tree(s) by seedling height group. Density per hectare was pooled over $50 \mathrm{~m}$ distance intervals from the source.

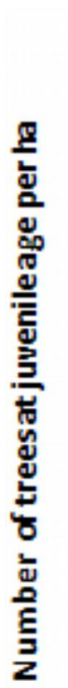

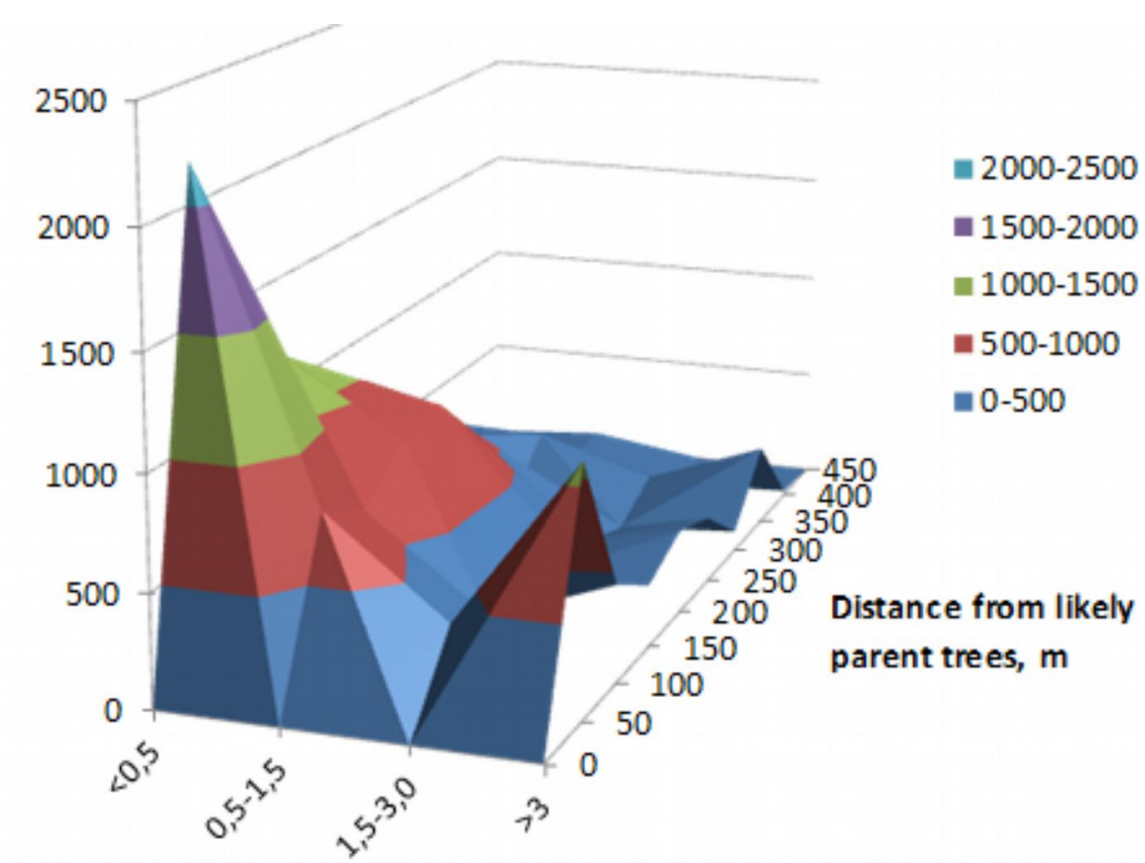

Height groups of trees at juvenile age, $m$

Tab. 2 - P-values of the Kolmogorov-Smirnov test for differences in seedling height classes and densities among the six sites analyzed. The P-values for the first (upper row) and second (lower row) classes are reported above the diagonal, while the third (upper row) and fouth (lower row) classes are reported below the diagonal.

\begin{tabular}{ccccccc}
\hline Site No. & $\mathbf{1}$ & $\mathbf{2}$ & $\mathbf{3}$ & $\mathbf{4}$ & $\mathbf{5}$ & $\mathbf{6}$ \\
\hline \multirow{2}{*}{$\mathbf{1}$} & - & 0.2372 & 0.1630 & $<.0001$ & 0.0068 & 0.0056 \\
& & 0.0591 & 0.6379 & 0.8001 & 0.3359 & 0.0643 \\
$\mathbf{2}$ & 0.4143 & & 0.6917 & 0.0004 & 0.0347 & 0.2109 \\
& 0.4143 & - & 0.2377 & 0.1411 & 0.0963 & 0.1203 \\
$\mathbf{3}$ & 0.1126 & 0.2011 & - & 0.0036 & 0.1147 & 0.3033 \\
& $<.0001$ & $<.0001$ & - & 0.8107 & 0.8208 & 0.4507 \\
$\mathbf{4}$ & $<.0001$ & $<.0001$ & 0.2001 & - & 0.8591 & 0.0218 \\
& 0.0387 & 0.0003 & 0.0267 & - & 0.9582 & 0.0851 \\
$\mathbf{5}$ & 0.1458 & 0.2562 & 0.9577 & 0.1258 & - & 0.2985 \\
& 0.0001 & $<.0001$ & 0.5671 & 0.0477 & - & 0.1250 \\
$\mathbf{6}$ & 0.9954 & 0.4392 & 0.3643 & 0.0083 & 0.8331 & - \\
\hline
\end{tabular}

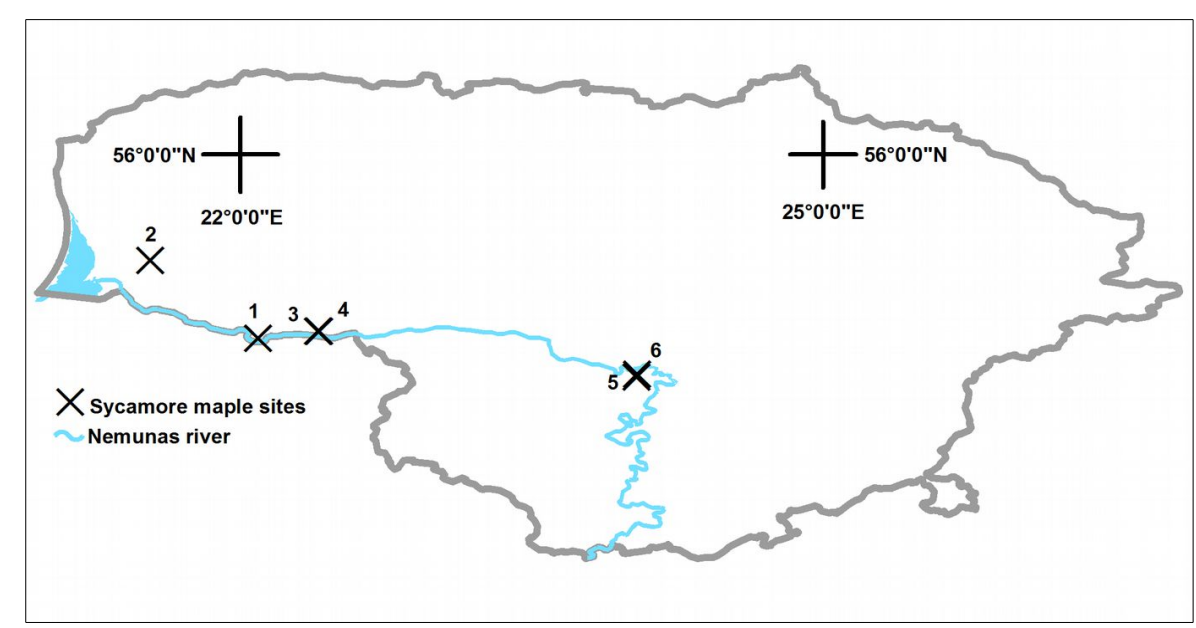

Fig. 2 - Location of sycamore maple sites used in this study. 
Tab. 3 - Groups and criteria weightings for determining the invasive degree.

\begin{tabular}{|c|c|c|c|c|c|}
\hline Group & Criteria & Notes & $\begin{array}{c}\text { Criteria } \\
\text { weightings }\end{array}$ & Rating & Impact \\
\hline \multirow[t]{3}{*}{ Establishment } & Germination requirements & $\begin{array}{l}\text { Seeds germinate in spring; seeds show dormancy (Pinfield } \\
\text { 1987); germination regimes: } 20^{\circ} \mathrm{C} \text {, continuous light, } 20 \mathrm{~d} \\
\text { (Pinfield et al. 1987) }\end{array}$ & 0.0425 & 0.75 & 0.032 \\
\hline & Establishment requirements & Occurs under moderate canopy forest, prefers moist soil & 0.3355 & 0.75 & 0.25 \\
\hline & Disturbance requ & Establishes in open woodlands, forest & 0.122 & 0.75 & 0.09 \\
\hline \multirow{5}{*}{$\begin{array}{l}\text { Growth/com- } \\
\text { petitive ability }\end{array}$} & Life form & Tree & 0.00576 & 0 & 0 \\
\hline & Allelopathic properties & Roots, leaves have moderate effect (Mensah 1972) & 0.00864 & 0.5 & 0.0043 \\
\hline & Tolerates herbivore pressure & $\begin{array}{l}\text { Roe deer browsing (Diaci 2002, Weidema \& Buchwald } \\
\text { 2010) }\end{array}$ & 0.0456 & 0.5 & 0.0228 \\
\hline & Normal growth rate & $\begin{array}{l}\text { Moderately rapid growth. One of the fastest growing trees } \\
\text { in Europe (Cronk \& Fuller 1995) }\end{array}$ & 0.018432 & 0.75 & 0.0138 \\
\hline & Stress tolerances & Tolerates frost, fire & 0.01776 & 0.5 & 0.0089 \\
\hline \multirow[t]{5}{*}{ Reproduction } & Reproductive system & Reproduces by seeds & 0.005593 & 0.25 & 0.0014 \\
\hline & Propagule production & Propagule density $\left(2064 \mathrm{ha}^{-1}\right)$ & 0.05474 & 1 & 0.054 \\
\hline & Seed longevity & $\begin{array}{l}\text { Seeds can be stored for } 3 \text { years at }-3^{\circ} \mathrm{C} \text { with } 24-32 \% \text { mc } \\
\text { (Suszka } 1978 \mathrm{a}, 1978 \mathrm{~b} \text { ) }\end{array}$ & 0.030464 & 0.25 & 0.0076 \\
\hline & Reproductive period & $\begin{array}{l}\text { Trees are long lived (350-400 years); tree produces new } \\
\text { growth each spring }\end{array}$ & 0.012019 & 1 & 0.012 \\
\hline & Time to reproductive maturity & Plants start flowering at 20 years of age (Navasaitis 2004) & 0.016184 & 0 & 0 \\
\hline \multirow[t]{2}{*}{ Dispersal } & Number of mechanisms & Propagules spread by wind, animals & 0.094572 & 0.5 & 0.0472 \\
\hline & How far do propagules disperse & Propagules will disperse several hundred metres & 0.189428 & 0.5 & 0.0947 \\
\hline \multicolumn{2}{|c|}{ Invasiveness Score } & $(\max .=1, \min .=0)$ & - & $\Sigma$ & 0.6426 \\
\hline
\end{tabular}

first two height classes $(\leq 0.5 \mathrm{~m}$ and $0.5-1.5$ $\mathrm{m})$ of the understory on fertile sites $(\mathrm{p}=$ 0.0175 and $p=0.0006$, respectively). The Pvalues from Kolmogorov-Smirnov test for differences among the six sites for seedling height classes and densities are presented in Tab. 2. The estimates clearly show that the smallest $(\leq 0.5 \mathrm{~m})$ and the largest $(>3 \mathrm{~m})$ seedling classes significantly differed among sites. Mantel's test using the total seedling quantity and the distance among sites resulted in a positive though not significant correlation $(r=0.56, \mathrm{p}>0.05)$. However, using the smallest class seedling quantity a significant result was obtained $(r=0.91, \mathrm{p}=$ 0.0263 ), while no significant correlations were detected by the Mantel's test carried out the largest class data and the distance among sites $(\mathrm{r}=0.21, \mathrm{p}>0.05)$.
Pearson's correlation coefficient between the underbrush cover and the quantity of sycamore maple seedlings was not statistically significant $(p>0.05)$. Nonetheless, it just revealed the tendency of a negative effect/relationship of underbrush cover on the quantity of seedlings in the first two height classes, as well as a positive effect on the fourth class (the largest seedlings). Underbrush cover was divided into two groups, the first including all the values below $50 \%$ and the other including all the values above such threshold. Differences in the quantity of seedlings in each height class were then tested using the Kolmogorov-Smirnov test, revealing significant differences in all but the third height class (1.5-3 m).

The age of the parent tree was positively correlated with the density of the largest

Tab. 4 - Intensity ratings for the ratio of present to potential distribution of sycamore maple.

\begin{tabular}{|c|c|c|}
\hline Rating & Weight & Regional Rating \\
\hline Very high & 1 & $\begin{array}{l}\text { Infestations that can be eradicated with no chance of reinvasion } \\
\text { from outside the area of control }\end{array}$ \\
\hline High & 0.85 & $\begin{array}{l}\text { Infestation(s) that can be eradicated with some chance of reinva- } \\
\text { sion }\end{array}$ \\
\hline Medium high & 0.71 & Several small infestations beyond eradication \\
\hline Medium & 0.57 & $\begin{array}{l}\text { A large partially dispersed infestation or a few widely scattered } \\
\text { small infestations }\end{array}$ \\
\hline Medium low & 0.42 & $\begin{array}{l}\text { Numerous large, dispersed infestations or many scattered, small in- } \\
\text { festations }\end{array}$ \\
\hline Low & 0.28 & $\begin{array}{l}\text { The majority of region is infested with some large areas still } \\
\text { "clean" (more "clean" areas than infested) }\end{array}$ \\
\hline Very low & 0.14 & $\begin{array}{l}\text { The majority of region is infested with some small areas still } \\
\text { "clean" (less "clean" areas than infested) }\end{array}$ \\
\hline Extremely low & 0 & $\begin{array}{l}\text { Reached full potential, but may increase in density within the in- } \\
\text { fested area }\end{array}$ \\
\hline
\end{tabular}

sycamore maple understorey seedlings ( $r=$ $0.83, \mathrm{p}<0.0001)$ and with the total quantity of seedlings $(r=0.51, \mathrm{p}=0.0354)$. The upper canopy layer density had positive effect on the quantities of smallest seedling group $(r=0.87, \mathrm{p}=0.0026)$ and negative on the largest group $(r=-0.77, \mathrm{p}=0.0154)$. Mean seedling spread distance from the parent tree was $257 \mathrm{~m}$.

\section{Sycamore maple invasiveness}

The invasiveness score obtained for sycamore maple in this study was 0.6426 (Tab. 3 ). The highest ratings were recorded for propagule density and the reproduction period (rating=1.0). Medium-high ratings $(0.75)$ were obtained by germination, growth rate, and establishment and disturbance requirements. In particular, the establishment features of the species mostly contribute $(58 \%)$ to increase the invasiveness score for sycamore maple.

The intensity ratings for the ratio of present to potential distribution are shown in Tab. 4. Based on data evaluation, a medium intensity rating was obtained (weight $=0.57$ ). Indeed, sycamore maple in Lithuania has been primarily recorded along the roadsides, in the riparian corridors and near the few parent tree plantations (Fig. 2).

Criteria ratings for determining the social, environmental and economic impacts of sycamore maple are shown in Tab. 5. Based on such ratings, the impact score obtained for sycamore maple was very low (0.1682).

In order to evaluate the relative importance of sycamore maple as invasive plant species in Lithuania, results from invasiveness (Tab. 
Tab. 5 - Group and criteria ratings for determining social, environmental and economic impacts.

\begin{tabular}{|c|c|c|c|c|}
\hline Group & No Criteria & Comments & Rating & Impact \\
\hline SOCIAL & 1 To what extent does the weed restrict human access? & Would not hinder human access & 0 & 0 \\
\hline $\begin{array}{l}\text { (Tourism, } \\
\text { Visual aesthetics, }\end{array}$ & $\begin{array}{l}2 \text { To what level does this weed reduce the tourism/aesthetics/recreational } \\
\text { use of the land? }\end{array}$ & $\begin{array}{l}\text { Sycamore not obvious to the aver- } \\
\text { age visitor }\end{array}$ & 0 & 0 \\
\hline \multirow{2}{*}{ Cultural sites) } & 3 To what level is the plant injurious, toxic or the spines affect people? & Not toxic and no spines & 0 & 0 \\
\hline & 4 How much damage is done to indigenous or European cultural sites? & No damage & 0 & 0 \\
\hline $\begin{array}{l}\text { NATURAL } \\
\text { RESOURCES }\end{array}$ & $\begin{array}{l}5 \text { To what extent does this weed impact water flow within watercourses or } \\
\text { water bodies? }\end{array}$ & No effect & 0 & 0 \\
\hline \multirow[t]{4}{*}{$\begin{array}{l}\text { (soil, water and pro- } \\
\text { cesses) }\end{array}$} & $\begin{array}{l}6 \text { To what extent does the weed impact water quality (i.e., dissolved } \mathrm{O}_{2} \text {, } \\
\text { water temperature)? }\end{array}$ & No impact & 0 & 0 \\
\hline & 7 To what extent does the weed increase soil erosion? & No increase & 0 & 0 \\
\hline & $\begin{array}{l}8 \text { To what extent does this weed reduce the biomass of the community? } \\
\text { (nb. biomass acting as a carbon sink). }\end{array}$ & $\begin{array}{l}\text { Biomass may increase in forest } \\
\text { gaps }\end{array}$ & 0 & 0 \\
\hline & 9 To what extent does the weed change the frequency or intensity of fires? & Can suppress fire in pine forests & 0 & 0 \\
\hline $\begin{array}{l}\text { Fauna and flora / } \\
\text { vegetation }\end{array}$ & $\begin{array}{l}10 \text { To what extent does this weed impact the vegetation (composition on the } \\
\text { following): }\end{array}$ & & & \\
\hline \multirow{5}{*}{ and EVCs } & a. High value EVCs & Minor displacement & 0.25 & 0.0205 \\
\hline & b. Medium value EVCs & Changes some dominant spp. & 0.5 & 0.0240 \\
\hline & c. Low value EVCs & Do not grow & 0 & \\
\hline & $\begin{array}{l}11 \text { To what extent does this weed affect the structure of a vegetation com- } \\
\text { munity? }\end{array}$ & $\begin{array}{l}\text { After long period, can affect trees, } \\
\text { shrubs and ground cover }\end{array}$ & 0.75 & 0.0518 \\
\hline & 12 What effect does the weed have on threatened flora? & Data not available & 0.5 & 0.0304 \\
\hline Flora and fauna / & 13 What effect does the weed have on threatened fauna? & No threatened fauna affected & 0 & 0. \\
\hline \multirow[t]{3}{*}{ fauna } & 14 What effect does the weed have on non-threatened fauna spp.? & $\begin{array}{l}\text { Alien moth eggs and larvae develop } \\
\text { in leaves }\end{array}$ & 0 & 0 \\
\hline & $\begin{array}{l}15 \text { To what extent does this weed benefit or facilitate the establishment of } \\
\text { indigenous fauna? }\end{array}$ & $\begin{array}{l}\text { Provides some food and shelter for } \\
\text { birds, mammals, insects }\end{array}$ & 0.75 & 0.0173 \\
\hline & $\begin{array}{l}16 \text { To what extent is the plant toxic or its burrs or spines affect indigenous } \\
\text { fauna? }\end{array}$ & No effect & 0 & 0 \\
\hline $\begin{array}{l}\text { FLORA AND } \\
\text { FAUNA/ FAUNA }\end{array}$ & 17 To what extent does this weed provide a food source for pest animals? & $\begin{array}{l}\text { Provides minimal food for pest ani- } \\
\text { mals }\end{array}$ & 0 & 0 \\
\hline /Pest Animal & 18 To what extent does this weed provide habitat/harbor for serious pests? & $\begin{array}{l}\text { May provide harbor for rabbits and } \\
\text { foxes throughout the year }\end{array}$ & 1 & 0.0168 \\
\hline $\begin{array}{l}\text { AGRICULTURE } \\
\text { (Quality, Quantity, }\end{array}$ & $\begin{array}{l}19 \text { 1To what extent does this weed impact on the quantity or } \\
\text { yield of agricultural produce? }\end{array}$ & $\begin{array}{l}\text { Little or negligible impact on quan- } \\
\text { tity of yield }\end{array}$ & 0 & 0 \\
\hline $\begin{array}{l}\text { Cost to } \\
\text { Production, }\end{array}$ & 20 To what extent does the weed impact on agricultural quality? & $\begin{array}{l}\text { Negligible impact on quality of } \\
\text { yield }\end{array}$ & 0 & 0 \\
\hline Effect on land & 21 To what extent does this weed affect land values? & None & 0 & 0 \\
\hline \multirow[t]{3}{*}{ use and value) } & $\begin{array}{l}22 \text { To what extent does this weed cause a change in land use } \\
\text { priorities? }\end{array}$ & No change & 0 & 0 \\
\hline & $\begin{array}{l}23 \text { To what extent does the presence of the weed increase the } \\
\text { cost of harvesting? }\end{array}$ & Little effect & 0 & 0 \\
\hline & $\begin{array}{l}24 \text { To what extent does this weed act as an alternative host or vector for dis- } \\
\text { eases of agriculture? }\end{array}$ & Not a host & 0 & 0 \\
\hline Total Impact Score & & - & $\Sigma$ & 0.1682 \\
\hline
\end{tabular}

3), distribution (Tab. 4) and impact (Tab. 5) assessments were than combined by calculating the Pest Plant Score (PPS - eqn. 3):

$$
\begin{aligned}
P P S & =0.12 \cdot 0.6426 \\
& +0.32 \cdot 0.57 \\
& +0.56 \cdot 0.1682=0.3537
\end{aligned}
$$

The obtained Pest Plant Score showed that, according to primary invasive parameters, the importance of sycamore maple as an invasive species was not high (0.3537), being lower than the average score $(0.5)$.

\section{Discussion and conclusion}

Alien species are typically more invasive in regions climatically similar to their native environment. The northern limit for sycamore maple's native geographic range is Poland (Boratynski 1999), where climate is only slightly harsher than in Lithuania. All current climate change scenarios predict for the Baltic region an increase in temperature and rainfall by at least $15 \%$ (Kjellström \& Ruosteenoja 2007), thus a shift northbound of the habitats suitable for sycamore maple is expected. Indeed, such species has the potential to colonize plant communities similar to those where it is currently found in Poland (Denisiuk et al. 1999), such as Fraxino-Ulmetum, Pino-Quercetum, Tilio-Carpinetum and others. In the present study, the largest sycamore maple spread was observed in stands dominated by birch, pine, maple and lime, though it can act as a pioneer species colonizing meadows and abandoned pastures (Rusanen \& Myking 2003).

In this investigation the average distance of maple seedlings from likely parent trees exceeds 200 meters, though other studies reported that very few seedlings may be found more than $50 \mathrm{~m}$ apart from parent trees (Degen 2006). The relatively high proportion of saplings up to $1.5 \mathrm{~m}$ in height suggests that a large part of the sycamore maple understorey is likely to reach the upper canopy layer. Small seedlings $(<50 \mathrm{~cm})$ can survive for long periods ( $>15$ years) under dense canopies where the light intensity is as low as $1 \%$ of the full light (Hättenschwiler \& Körner 2000). Such characteristics, along with the rapid juvenile growth, allow the sycamore maple to colonize neighboring stands with dense canopies, especially where the competition in the understorey layer is low (Hein et al. 2009).

Studies of regeneration of broadleaved species in northeastern France showed that 13 years after gap creation, the understorey species composition was dominated by $\mathrm{Fa}$ gus sylvatica and Acer pseudoplatanus seedlings (Collet et al. 2008), with density for the latter species reaching 19000 per hectare and the mean seedling height of 0.7 $\mathrm{m}$. In our study sites, such high density were not reached since the scattered distribution of the A. pseudoplatanus parent trees, 
though the average height of seedlings was close to that reported by Collet et al. (2008).

In our study sites, density of Norway maple (A. platanoides) or small-leaved lime (Tilia cordata) seedlings in the understorey locally reached that of sycamore maple, but with a lower mean seedling height. Moreover, their distance from parent tree was lower than that recorded for sycamore maple. Furthermore, later bud flushing of $A$. pseudoplatanus as compared to $A$. platanoides allows their seedlings to avoid spring frost (Chylarecki \& Straus 1968).

In Lithuania, the highest invasiveness among forest tree species was reported for boxelder (Acer negundo L. - Valantinaite et al. 2011), with a $P P S$ of 0.464 , followed by the red oak (Quercus rubra L. - Riepšas \& Straigyte 2008). As compared to such species, sycamore maple showed an invasiveness much lower (0.354). However, its impact on the local biocoenosis should not be underestimated. Indeed, litter decomposition rate after 12 months was $30.4 \%$ for red oak (Straigyte \& Žalkauskas 2012) and $43.5 \%$ for sycamore maple, suggesting a greater influence of the latter species on the microbial community.

In Denmark, the invasive capacity of sycamore maple has been widely exploited since the late 1960 s to achieve reliable, rapid, and inexpensive establishment of a new generation of trees in canopy gaps following conifer wind throw (Jensen 1983, Tillisch 2001). In Lithuania, sycamore invasion has only been observed in recent years when it started to colonize the understorey of forest stands, determining a gradual changes in tree species composition.

High timber prices and rapid growth rates have made sycamore maple economically attractive. However, our results show that sycamore maple spreads rapidly from its planted locations. Therefore, a cautious approach should be taken when establishing new sycamore maple forest plantations.

\section{References}

Alisov BP (1954). Die Klimate der Erde [Climates of the Earth]. Deutscher Verlag der Wissenschaften, Berlin, Germany, pp. 277. [in German] Anonymous (2004). Victorian pest plant prioritisation process: methodology. Victorian Resources Online, Dept. of Economic Development, Jobs, Transport and Resources, Melbourne, Australia, pp. 38. [online] URL: http://vro.depi.vic.gov.au/dpi/vro/vrosite.nsf/pages/weeds_listing_d ocs/\$FILE/VPPPP_Methodology_rev.doc

Binggeli P (1992). Patterns of invasion of sycamore (Acer pseudoplatanus L.) in relation to species and ecosystem attributes. PhD Thesis, University of Ulster, Londonderry, UK.

Boratynski A (1999). Systematyka I geograficzne rozmieszczenie [Systematics and geographical distribution]. Monografie "Nasze drzewa lesne", volume 18, Klony, Polish Science Academy, Poz-
nan-Kornik, Poland, pp. 15-73. [in Polish]

Burschel P, Huss J (1997). Lehrbuch des waldbaus: ein leitfaden für studium und praxis [Textbook of silviculture: a guide for the study and practice] ( $2^{\text {nd }}$ edn). Parey Verlag, Berlin, Germany, pp. 487. [in German]

Chylarecki H, Straus H (1968). Wyniki dziesiecioletnich obserwacji fenologicznych nad drzewami i krzewami w Arboretum Kornickim [Results of ten-year phenological observations over trees and shrubs in the Kórnickie arboretum]. Arbor. Kornickie 13: 37-120. [in Polish]

Collet C, Piboule A, Leroy O, Frochot H (2008). Advance Fagus sylvatica and Acer pseudoplatanus seedlings dominate tree regeneration in a mixed broadleaved former coppice-with-standards forest. Forestry 81(2): 135-150. - doi: 10.1093/forestry/cpn004

Cronk QCB, Fuller JL (1995). Plant invaders: the treath to natural ecosystems. Chapman and Hall, New York, USA, pp. 241.

Denisiuk Z, Kurczynski J, Mielnicka B, Pilipowicz W (1999). Rodzime klony w obszarach I obiektach chronionych w Polsce [Native maples in protected areas in Poland]. Monografie "Nasze Drzewa Lesne", volume 18, Klony. Polish Science Academy, Poznan-Kornik, Poland, pp. 567642. [in Polish]

Degen T (2006). Dynamique initiale de la végétation herbacée et de la régénération ligneuse dans le cas de trouées, au sein d'une hêtraie (LuzuloFagetum). Quels enseignements tirer de la tempête de décembre 1999 dans les Vosges du Nord? [Initial dynamics of herbaceous and woody regeneration in the case of holes, in a beech forest (Luzulo-Fagetum). What can we learn from December 1999 storm in the northern Vosges?]. $\mathrm{PhD}$ dissertation, Université Catholique de Louvain, Belgium, pp. 342. [in French]

Diaci J (2002). Regeneration dynamics in a Norway spruce plantation on a silver fir-beech forest site in the Slovenian Alps. Forest Ecology and Management 161: 27-38. - doi: 10.1016/S03781127(01)00492-3

Galvonaite A, Misiuniene M, Valiukas D, Buitkuviene MS (2007). Lietuvos klimatas [Lithuanian climate]. Monography, Vaga, Vilnius, Lithuania, pp. 207. [in Lithuanian]

Hättenschwiler S, Körner C (2000). Tree seedling responses to in situ $\mathrm{CO}_{2}$-enrichment differ among species and depend on understorey light availability. Global Change Biology 6: 213-226. - doi: 10.1046/j.1365-2486.2000.00301.x

Hein S, Collet C, Ammer C, Le Goff N, Skovsgaard JP, Savill P (2009). A review of growth and stand dynamics of Acer pseudoplatanus L. in Europe: implications for silviculture. Forestry 82 (4): 361-385. - doi: 10.1093/forestry/cpn043

Januškevičius L, Baroniene V, Liagiene D (2006). Sumedejusiu augalu introdukcija ir aklimatizacija bei ju rezultatai ir perspektyvos Lietuvoje [Woody plant introduction and acclimatization: results and prospects for Lithuania]. Lutute, Kaunas, Lithuania, pp. 392. [in Lithuanian] Jensen NPD (1983). Ærdyrkning specielt med henblik på Sjælland og Lolland-Falster [Syca- more maple cultivation, especially for growing on Seeland and Lolland]. Dansk Skovforenings Tidsskrift 58: 333-360. [in Danish]

Jones EW (1945). Biological flora of the British Isles, Acer L. Journal of Ecology 32: 215-252. doi: $10.2307 / 2256711$

Kjellström E, Ruosteenoja K (2007). Present-day and future precipitation in the Baltic Sea region as simulated in a suite of regional climate models. Climatic Change 81 (1): 281-291.

Kölling C (2007). Klimahüllen für 27 waldbaumarten [Climate envelope for 27 forest tree species]. Allgemeine Forstzeitschrift/ Der Wald 23: 1242-1245. [in German]

Kölling C, Zimmermann L (2007). Die Anfälligkeit der Wälder Deutschlands gegenüber dem Klimawandel [The vulnerability of German forests to climate change]. Gefahrstoffe 67: 259268. [in German]

Lichstein JW, Grau HR, Aragon R (2004). Recruitment limitation in secondary forest dominated by an exotic tree. Journal of Vegetation Science 15 (6): 721-728. - doi: 10.1111/j.16541103.2004.tb02314.x

Mensah KOA (1972). Allelopathy as expressed by sugar maple on yellow birch. Dissertation Abstract, International B. Science and Engineering 33: $1877-1839$

Navasaitis M (2004). Dendrologija. Margi rastai, Vilnius, Lithuania, pp. 856. [in Lithuanian] Panetta FD, Dodd J (1987). Bioclimatic prediction of the potential distribution of skeleton weed (Chondrilla juncea L.) in western Australia. Journal of the Australian Institute of Agricultural Science 53: 11-16.

Pinfield NJ (1987). Seed dormancy: changing concepts of its regulation. In: "Growth regulatiors and seeds" (Black M eds). British Plant Growth Regular Group, Monograph, vol. 15, British Plant Growth Regular Group, Bristol, UK, pp. 1-15.

Pinfield NJ, Stutchbury PA, Bazaid SM (1987). Seed dormancy in Acer: is there a common mechanism for all Acer species and what part is played in it by abscisic acid? Physiologia Plantarum 71: 365-371. - doi: 10.1111/j.13993054.1987.tb04357.x

Riepšas E, Straigyte L (2008). Invasiveness and ecological effects of Red Oak (Quercus rubra L.) in Lithuanian forests. Baltic Forestry 14 (2): 122-130.

Rusanen M, Myking T (2003). EUFORGEN technical guidelines for genetic conservation and use for Sycamore (Acer pseudoplatanus). International Plant Genetic Resources Institute, FAO, Rome, Italy, pp. 6. [online] URL: http://www.euforgen.org/fileadmin/bioversity/publications/pdfs /853_Technical_guidelines_for_genetic_conservation_and_use_for_Sycamore_Acer_pseudoplatanus .pdf

Saaty T (1995). Decision making for leaders: the analytical hierarchy process for decisions in a complex world. RWS Publications, Pittsburgh, PA, USA, pp. 292.

Skridaila A (2001). Introduction of woody plants in Vilnius University Botanical Garden in 1781- 
2000. PhD thesis, Nature Sciences Department, Vilnius University, Lithuania, pp.135. [in Lithuanian]

Straigyte L, Zalkauskas R (2012). Effect of climate variability on Quercur rubra L. phenotype and spread in Lithuanian forest. Dendrobiology 67: $79-85$.

Suszka B (1978a). Germination of tree seed stored in a partially after ripened condition. Acta Horticulturae 83: 181-187.

Suszka B (1978b). How to achieve simultaneous germination of after-ripened hardwood seed. In Proceedings of the "Symposium on establishment and treatment of high quality hardwood forests in the temperate climatic region". Nancy -
Champenoux (France) 11-15 sep 1978. INRA, Centre National de Recherches Forestieres 78/08, France, pp. 30-40.

Tillisch E (2001). Æren trænger sig frem [The sycamore maple is spreading]. Dansk Skovbrugs Tidsskrift 86: 1-96. [in Danish]

Valantinaite A, Straigyte L, Jurkšiene G (2011). Comparative analysis of invasion intensity of box elder (Acer negundo L.) and sosnowskyi hogweed (Heracleum sosnowskyj Manden). Rural Development 5 (2): 161-166.

Vitousek PM, Walker LR (1989). Biological invasion by Myrica faya in Hawaii: plant demography, nitrogen fixation, ecosystem effects. Ecological Monographs 59: 247-265. - doi:
$10.2307 / 1942601$

Weidema I, Buchwald E (2010). NOBANIS - Invasive alien species fact sheet - Acer pseudoplatanus. [online] URL: http://www.nobanis.org/ files/factsheets/Acer_pseudoplatanus.pdf Weiss J, McLaren D (2002). Victoria's pest plant prioritisation process. In: Proceedings of the " $13^{\text {th }}$ Australian weeds conference" (Dodd J, Moore JH, Spafford HJ eds). Perth (Australia), 813 sep 2002. Plant Protection Society of Western Australia, Perth, Australia, pp. 509-512.

Williamson M, Fitter A (1996). The varying success of invaders. Ecology 77: 1661-1666. - doi: $10.2307 / 2265769$ 